\title{
EVALUASI SISTEM AKUNTANSI MANAJEMEN TERHADAP KELANCARAN PROSES PRODUKSI PADA PT. SEMEN BOSOWA
}

\section{Edi Jusriadi}

edijusriadi@unismuh.ac.id

\section{Ario}

ario@unismuh.ac.id

Fakultas Ekonomi dan Bisnis

Universitas Muhammadiyah Makassar

\begin{abstract}
This study aims to determine how the influence of management accounting system evaluation on the smooth process of cement production at PT. Semen Bosowa Maros. This type of research used in this research is descriptive method. Data collection techniques using observation and interviews. The results showed that PT Semen Bosowa Maros had done this well because the Management Accounting System Evaluation was carried out systematically and structured starting from the time of production planning, production process control and performance coordination. and in the annual production of PT Semen Bosowa from 2014 to 2018 decreased as an adjustment to the level of cost realization which also increased in that year.
\end{abstract}

Key words : Management Accounting System and Production Process

\begin{abstract}
Abstrak
Penelitian ini bertujuan untuk mengetahui Bagaimana pengaruh evaluasi sistem akuntansi manajemen terhadap kelancaran proses produksi semen pada PT. Semen Bosowa Maros. Jenis penelitian yang digunakan dalam penelitian ini adalah metode deskriptif. teknik pengumpulan data menggunakan yaitu observasi dan wawancara. Hasil penelitian menunjukan bahwa PT Semen Bosowa Maros telah dilakukan dengan baik hal ini karena Evaluasi Sistem Akuntansi manajemen dilakukan secara sistematis dan terstruktur mulai saat perencanaan produksi, pengendalian proses produksi serta koordinasi kinerja. dan pada produksi tahunan PT Semen Bosowa mulai tahun 2014 sampai tahun 2018 mengalami penurunan sebagai penyesuaian tingkat realisasi biaya yang meningkat pula pada tahun tersebut.
\end{abstract}

Kata Kunci: Sistem Akuntansi Manajemen dan Proses Produksi 


\section{PENDAHULUAN}

Perkembangan sistem akuntansi manajemen saat ini sudah sangat pesat. Perusahaan memerlukan sistem akuntansi manajemen dalam melaksanakan fungsi perencanaan, pengendalian dan pengambilan pengambilan keputusan. Sistem akuntansi manajemen yang terdapat dalam suatu perusahaan pada dasarnya memiliki tiga tujuan utama yaitu: perencanaan, pengendalian, evaluasi dan perbaikan berkesinambungan, serta memberikan informasi untuk pengambilan keputusan. Manajemen memerlukan sistem evaluasi kinerja yang dapat membantu dalam mengevaluasi prestasi kinerja perusahaan melalui kinerja manajer pada berbagai tingkat pusat pertanggungjawaban (Raino, 2013).

Sejalan dengan perkembangan teknologi, jenis-jenis produk makin bertambah jumlahnya, seiring dengan itu pula, persoalan yang dihadapi perusahaan terutama perusahaan manufaktur akan semakin kompleks, hal ini menuntut manajemen perusahaan untuk menetukan suatu tindakan dengan memilih berbagai alternative dan kebijakasanaan dalam mengambil keputusan yang sebaikbaiknya agar tujuan perusahaan dapat tercapai.

Organisasi menjadi kian kompleks, instensitas kebutuhan data dan informasi untuk mengelola dan mengendalikan perusahaan meningkat. Pertumbuhan organisasi ini harus didukung dengan penyediaan, pengelolaan, dan pendistribusian data dan informasi secara terpadu. Sistem informasi manajemen berperan penting menyediakan, mengelola, dan mendistribusikan data dan informasi ini, sesuai kebutuhan tugas dan fungsi setiap divisi. Akuntansi manajemen mampu merangkum data yang beragam dari berbagai fungsi organisasi menjadi satu laporan yang dapat dipahami oleh semua pihak yang berkepentingan. Agar fungsi akuntansi manajemen ini optimal maka diperlukan sistem dan prosedur formal dalam aktivitas perencanaan, pengendalian, dan penilaian kinerja. Kualitas data dan informasi yang dihasilkan menentukan kualitas keputusan yang diambil oleh manajemen.

Perusahaan mendesain sistem akuntansi manajemen dalam membantu organisasi yang bersangkutan melalui manajernya, yaitu dalam perencanaan, pengorganisasian, pengarahan dan pengambilan keputusan (Lempas, 2014). Aktivitas para manajer membutuhkan dukungan informasi. Sistem akuntansi manajemen merupakan sistem formal yang dirancang untuk menyediakan informasi bagi manajer. Perencanaan sistem akuntansi manajemen yang merupakan bagian dari sistem pengendalian organisasi perlu mendapat perhatian, hingga dapat diterapkan akan memberikan kontribusi positif dalam keberhasilan sistem pengendalian manajemen. Peningkatan kinerja manajerial diharapkan akan meningkatkan kinerja perusahaan. Informasi sangat berguna bagi perusahaan dalam kegiatan perencanaan, control, dan pengambilan suatu perusahaan akan tergantung pada factor struktur organisasi perusahaan.

Dari uraian diatas dapat disimpulkan bahwa informasi merupakan mesin yang membuat manajer berjalan. Dalam ketiadaan aliran informasi yang kontinu, manajemen akan menjadi tidak berdaya melakukan sesuatu. Informasi akuntansi salah satunya, yang juga masih tergantung kepada para pakar bidang lainnya dalam menyediakan sebagian kebutuhan informasi pendukung, ahli ekonomi, ahli pemasaran, ahli perilaku 
organisasi, dan lain-lainmya. Dapat memberikan informasi kepada manajemen atau mengemukakan saran atas berbagai tahap aktivitas organisasi.

Dihubungkan peranan akuntansi dengan manajemen dalam keputusan manajerial saja diharapkan tentu dapat membantu manajer dalam membuat keputusan-keputusan khusus manajemen. Para manajer adalah orang yang ditunjuk pemilik perusahaan atau pemegang saham untuk menjalankan roda perusahaan dengan baik dan benar. Akuntansi manajemen adalah suatu bidang ilmu akuntansi yang akan membantu para manajer dalam membuat scenario atau rekayasa dalam mengambil keputusan taktis, yang akan diambil manajemen.

Keputusan menerima atau menolak pesanan khusus, keputusan pembelian atau pembuatan komponen produk, keputusan penyewaan atau penggunaan kapasitas, keputusan meneruskan atau penghentian penjualan kelompok produk tertentu dan keputusan untuk menutup usaha sementara, apakah suatu lini produk akan ditutup atau tidak, atau dalam pemilihan investasi apakah akan membeli mesin baru atau memperbaiki mesin lama. Keberhasilan suatu organisasi bisnis diera yang sarat dengan persaingan tergantung dari kesiapan suatu perusahaan dalam menghadapi tantangan dan ancaman yang timbul yaitu dengan mengetahui informasi manajemen perusahaan (Octavia Ferona Ingkiriwang, 2013). Orang yang tidak terencana berpikir pendek dan mencari yang serba instan dan mencari produk yang bisa memberikan keuntungan jangka pendek untuk menyelesaikan masalah yang ada didepan mata saja (Dhameria, 2014).

Penelitian ini termotivasi dari penelitian yang dilakukan oleh Entar Sutisman tentang pengaruh sistem akuntansi manajemen terhadap kinerja produksi pada PT X. bahwa penerapan sistem akuntansi manajemen menunjukkan produktivitas kinerja yakni efektivitas dan efisiensi mampu berjalan dengan baik. Dari hal ini penulis melihat perlu adanya suatu evaluasi terkait dengan penerapan sistem akuntansi manajemen yang berfokus pada proses produksi suatu perusahaan, sehingga tercipta pengendalian yang baik dalam menunjang kelancaran proses produksi.Berdasarkan uraian tersebut di atas maka penulis memilih judul sebagai berikut: "Evaluasi Sistem Akuntansi Manajemen Terhadap Kelancaran Proses Produksi PT. Semen Bosowa Maros".

\section{TINJAUAN PUSTAKA}

\subsection{Akuntansi Manajemen}

Akuntansi manajemen merupakan salah satu bidang ilmu dari akuntansi yang mempelajari bagaiamana cara menghasilkan informasi keuangan untuk pihak manajemen yang selanjutnya akan digunakan untuk pengambilan keputusan. Umumnya informasi yang dihasilkan sifatnya lebih dalam dan tidak dipublikasikan. (Sujarweni 2015:5)

Tujuan akuntansi manajemen adalah sebagai berikut:

1. Menyediakan informasi yang bisa dugunakan untuk menghitung HPP (Harga pokok produksi dan jasa, dan tujuan lain yang diinginkan manajemen).

2. Menyediakan informasi dalam rangka melakukan

pengevaluasian, perencanaan, berkelanjutan, dan pengambilan keputusan.

$$
\text { Jamaluddin Majid }
$$
mengemukakan bahwa terdapat dua garis besar peranan dari akuntansi manajemen, antara lain: 
1. Peran akuntansi manajemen sebagai suatu tipe akuntansi. Peran akuntansi manajemen sebagai sistem pengolah informasi keuangan dalam perusahaan dibagi menjadi tiga tingkat perkembangan:

a. Pencatat skor (score keeping)

Dalam pengelolaan perusahaan, manajemen melakukan perencanaan aktivitas dan pengendalian pelaksanaan rencana aktivitasnya. Akuntansi manajemen berperan dalam menyediakan informasi keuangan bagi penyusun rencana aktivitas, yang, memberikan informasi sebagai dasar untuk mengalokasikan sumber daya kepada berbagai aktivitas yang direncanakan.

b. Penarik perhatian manajemen Sebagai penarik perhatian manajemen, akuntansi menyajikan informasi penyimpangan pelaksanaan rencana yang memerlukan perhatian manajemen, agar manajemen dapat merumuskan tindakan untuk mencengah berlanjutnya penyimpangan yang terjadi.

c. Penyedia informasi untuk mencegah masalah

Tahap perkembangan ini merupakan akibat lebih lanjut dari status perkembangan yang sebelumnya telah dicapai, yaitu sebagai pencatat skor dan penarik perhatian. Jika manajemen telah mengandalkan informasi yang dihasilkan oleh akuntan manajemen maka mereka akan selalu mengundangnya dalam setiap pengambilan keputusan pemecahan masalah yang akan mereka lakukan. d. Peran akuntansi manajemen sebagai suatu tipe informasi.

Informasi merupakan suatu fakta, data, pengamatan, persepsi, atau sesuatu yang lain, yang menambah pengetahuan. Informasi diperlukan oleh manusia untuk mengurangi ketidakpastian dalam pengambilan keputusan.

Disamping uraian mengenai garis besar pentingnya akuntansi manajemen dalam suatu proses bisnis, peran akuntansi manajemen sebagai pelaksana sistem akuntansi manajemen juga tidak kalah penting, serta merupakan peran pendukung dalam suatu organisasi. Mereka membantu orang-orang bertanggungjawab dalam tujuan dasar organisasi. (Hansen, 2009:20)

\subsection{Peran Akuntansi Manajemen Dalam Organisasi Penentuan Kos Produksi Barang/Jasa.}

Salah satu alasan utama perlunya akuntansi manajemen adalah penetuan kos dan pendapatan yang terjadi dalam sebuah organisasi, meliputi berikut ini.

a. Bahan baku, bahan habis pakai, yang digunakan dalam produksi dan aktivitas lainnya, seperti pemeliharaan dan administrasi.

b. Kos tenaga kerja dan kos overhead yang digunakan.

c. Kos produksi atas pekerjaan, pesanan yang dihasilkan oleh organisasi.

d. Kos produksi jasa yang dihasilkan organisasi untuk konsumennya

e. Kos produksi suku cadang yang menjadi bagian kecil dari produksi yang lebih besar lagi.

f. Kos yang dikomsumsi oleh divisi, departemen dalam organisasi.

g. Kos produksi atas serangkaian proses produksi yang terjadi sebelum dihasilkan produk final. 
Sistem akuntansi manajemen tidak akan membebankan kos hanya pada satu bagian organisasi. Akuntan manajemen bersama dengan manajemen lainnya akan menentukan kos apa yang akan dibebankan melalui sistem dan mengalokasikannya sesuai dengan produk dan jasa yang dihasilkan serta metode produksi yang digunakan. Sistem akuntansi manajemen juga akan mengidentifikasikan pendapatan dari produk dan divisi yang ada.

\subsection{Sistem Akuntansi Manajemen}

Suprayogy

(2010:11)

mengemukakan bahwa sistem adalah suatu cara tertentu dan biasanya berulang untuk melaksanakan suatu cara atau serangkaian aktivitas. Supriyono (2002:3) mendefinisikan sistem akuntansi manejemen adalah proses identifikasi, pengukuran, pengumpulan, analisis, penyiapan, dan komunikasi informasi finansial yang digunakan oleh manajemen untuk perencanaan, evaluasi, pengendalian dalam suatu organisasi, serta menjamin ketepatan penggunaan sumber-sumber dan pertanggungjawaban atas sumber-sumber tersebut.

Menurut Hansen dan Mowen (2009:4) menyatakan bahwa sistem informasi akuntansi manajemen menyediakan informasi yang dibutuhkan untuk memenuhi tujuan-tujuan manajemen tertentu. Inti dari sistem informasi akuntansi manajemen adalah proses yang dideskripsikan oleh aktivitasaktivitas seperti pengumpulan, pengukuran, penyimpanan, analisis, pelaporan, dan pengelolaan informasi. Informasi mengenai peristiwa ekonomi diproses untuk menghasilkan keluaran (output) yang memenuhi sistem tersebut. Keluaran itu bisa bisa mencakup laporan khusus, biaya produk, biaya pelanggan, anggaran, laporan kinerja, bahkan komunikasi pribadi.

Sistem informasi akuntansi manajemen tidak terikat oleh kriteria formal apapun yang mendefinisikan sifat dari proses, masukan, atau keluarannya. Kriterianya fleksibel dan berdasarkan pada tujuan mananjemen.

Sistem akuntansi manajemen memiliki tiga tujuan sebagai berikut:

1. Menyediakan informasi untuk perhitungan biaya jasa, produk, atau objek lainnya yang ditentukan oleh manajemen.

2. Menyediakan informasi untuk untuk perencanaan, pengendalian, pengevalusian, dan perbaikan berkelanjutan.

3. Menyediakan informasi untuk pengambilan keputusan.

Ketiga tujuan ini menunjukkan manajer dan pengguna lainnya perlu memiliki akses menuju informasi akuntansi manajemen dan perlu mengetahui cara penggunaanya. Informasi akuntansi manjemen dapat membantu mereka membantu mereka mengindentifikasi dan menyelesaikan masalah semua tahap manajemen, termasuk perencanaan, pengendalian dan pengambilan keputusan. Selain itu, kebutuhan atas informasi ini tidak terbatas hanya pada perusahaan manufaktur, tetapi juga pada perusahaan perdagangan, jasa, dan nirlaba.

\subsection{Informasi Akuntansi Manajemen}

Informasi akuntansi pada dasarnya bersifat keuangan yang membantu manajer melakukan tiga masalah pokok sebagai berikut: (Kamaruddin Ahmad 2014:3)

1. Merencanakan secara efektif dan merumuskan perhatiannya pada penyimpangan apa yang direncanakan. 
Penyediaan informasi akuntansi yang dapat membantu kebutuhan manajer melalui penyediaan laporan prestasi yang membantu manajer memusatkan terhadap masalah.

2. Mengarahkan operasi sehari-hari Manajer mempunyai kebutuhan yang konstan akan informasi akuntansi dalam memimpin operasi sehari-hari yang rutin. Misalnya sewaktu manajer menentukan harga pokok produk yang bersandar pada informasi yang disediakan akuntansi untuk memastikan hubungan harga dan biaya sudah serasi dengan strategi pemasaran yang digunakan oleh perusahaan.

3. Mencapai penyelesaian terbaik sehubungan dengan masalah operasi yang dihadapi organisasi

Informasi akuntansi sering
merupakan factor penting dalam
menganalisis alternative penyelesaian
masalah. Alasannya ialah bahwa berbagai
alternative, biasanya mempunyai biaya
dan manfaat tertentu yang dapat diukur
dan digunakan sebagai masukan dalam
memutuskan alternative terbaik.
Informasi akuntansi secara garis besar dapat digambarkan sebagai rangkaian aktivitas yang menggambarkan pemrosesan data-data dari aktivitas bisnis pengolahan data keuangan perusahaan dengan menggunakan sistem informasi computer yang terintengrasi secara harmonis.(Lilis Puspitawati dan Sri Dewi Anggadani 2011:57).

Sistem informasi akuntansi dapat pula didefinisikan sebagai suatu sistem yang berfungsi untuk mengorganisir formulir, catatan dan laporan yang dikoordinasi untuk menghasilkan informasi yang dibutuhkan dalam pembuatan keputusan manajemen dan pemimpin perusahaan dan dapat memudahkan pengelolaan perusahaan.

\subsection{Biaya Produksi}

Dalam pembuatan produk terdapat dua kelompok biaya yaitu biaya produksi dan biaya non produksi. Menurut Ahmad (2013:34) biaya produksi adalah biaya yang dikeluarkan untuk menghasilkan suatu barang. Biaya produksi merupakan biaya yang berkaitan dengan pembuatan barang dan penyediaan jasa. Biaya produksi dapat diklasifikasikan lebih lanjut sebagai biaya bahan langsung, Tenaga kerja langsung, dan overhead pabrik. Sedangkan biaya non produksi adalah biaya yang berkaitan selain fungsi produksi yaitu, pengembangan, distribusi, layanan pelanggan dan administrasi umum.

Biaya produksi adalah semua pengeluaran ekonomis yang harus di keluarkan untuk memproduksi suatu barang. Biaya produksi juga merupakan pengeluaran yang dilakukan perusahaan untuk mendapatkan factor-faktor produksi dan bahan baku yang akan digunakan untuk menghasilkan suatu produk. Menurut Garisson et al (2006:51) perusahaan manufaktur membagi biaya kedalam tiga kategori besar yaitu:

1. Bahan langsung (direct material)

Bahan langsung adalah bahan yang digunakan untuk menghasilkan produk jadi. Sesungguhnya bahan baku berkaitan dengan semua jenis bahan yang digunakan dalam pembuatan produk jadi, dan produk jadi suatu perusahaan dapat menjadi bahan baku perusahaan yang lainnya.

2. Tenaga Kerja Langsung (direct labour) Biaya tenaga kerja langsung (direct labour) adalah biaya yang digunakan untuk biaya tenaga kerja dan dapat ditelesuri dengan mudah ke produk jadi. Tenaga kerja langsung biasanya 
disebut juga tenaga kerja manual (touch labour) karena tenaga kerja langsung melakukan kerja tangan atas produk pada saat produksi.

3. Biaya Overhead Pabrik (manufacturing overhead).

Pengertian biaya overhead pabrik adalah termasuk seluruh biaya yang tidak termasuk dalam bahan langsung dan tenaga kerja langsung. Biaya overhead pabrik termasuk bahan tidak langsung, tenaga kerja tidak langsung, pemeliharaan dan perbaikan peralatan produksi, listrik dan penerangan, pajak property, depresiasi, dan asuransi fasilitas-fasilitas produksi.

\subsection{Kinerja Produksi}

kinerja produksi merupakan suatu pekerjaan yang telah dihasilkan dalam suatu proses yang dimulai dari input dan menghasilkan output. Produktivitas memiliki dua dimensi produktivitas kinerja yakni efektivitas dan efisiensi. Dimensi pertama berkaitan dengan pencapaian untuk kinerja yang maksimal, dalam arti pencapaian target yang berkaitan dengan kualitas, kuantitas dan waktu. Sedangkan dimensi kedua berkaitan dengan upaya membandingkan masukan dengan realisasi penggunaannya atau bagaimana pekerjaan tersebut dilaksanakan. Berdasarkan penjelasan diatas, dapat diartikan bahwa untuk mengukur suatu suatu produktivitas diperlukan dua dimensi yaitu efektivitas dan dimensi efisiensi, yang keduanya saling berkaitan satu sama lain dalam pencapaian target yang berkaitan, berupa kualitas yang maksimal.

Efektivitas merupakan suatu ukuran yang memberikan gambaran seberapa jauh target dapat dicapai. Pengertian efektivitas ini lebih berorientasi pada keluaran (output), sedangkan masalah masukan kurang menjadi perhatian khusus atau utama. Oleh karena itu keterkaitannya dengan produktivitas kerja tingkat keefektifan aparatur atau pegawai sangat penting untuk menghasilkan suatu output. Berbeda dengan efektivitas, keterkaitan efisiensi dengan produktivitas lebih beorientasi terhadap suatu ukuran dalam membandingkan penggunaan masukan yang sebenarnya terlaksana. Singkatnya pengertian efisiensi disini lebih berorerientasi pada masukan. Sedangkan masalah keluaran (output) kurang menjadi perhatian utama.

\subsection{Pengendalian Terhadap Kinerja Produksi.}

Wardan dan Ja'far (2009:6) menyatakan bahwa, pengendalian merupakan proses yang digunakan oleh manajemen agar para pelaksana bekerja dengan efektif dan efisien dalam rangka mencapai tujuan organisasi atau tujuan bagian organisasi yang telah ditentukan terlebih dahulu. Sedangkan menurut Anthony dan Govindarajan (1995), (dalam Sumarno, 2006:1) mendefinisikan sitem pengendalian manajemen sebagai proses seorang manjer memastikan bahwa sumberdaya diperoleh dan digunkan secara efektif dan efisien dalam usaha untuk mencapai tujuan organisasi penelitian tentang sistem pengendalian manajemen, konsep pengendalian majemen dirasakan sebagai proses yang dirancang untuk menanggulangi aktivitasaktivitas produksi yang terjadi dalam suatu organisasi. Sebagai konsekuensinya pemahaman tentang sistem pengendalian manajemen hanya didasarkan pada mekanisme penginvestasian yang diimplementasikan oleh manajemen untuk mengendalikan pekerjaan melalui pengamatan dan pemantauan perilaku dan output/efektivitas. (Sumarno 2006:1). 


\subsection{Kordinasi terhadap Kinerja Produksi}

Koordinasi didefinisikan sebagai proses pengintegrasian (penyatuan) tujuan dan kegiatan perusahaan pada satuan yang terpisah dalam suatu organisasi untuk mencapai tujuan organisasi secara efisien dan efektif, yaitu dalam proses produksi. Koordinasi dan kinerja produksi merupakan koordinasi yang dibutuhkan sekali oleh para karyawan, seperti pada proses produksi, sebab tanpa koordinasi setiap karyawan tidak mempunyai pegangan mana yang harus diikuti, yang akhirnya akan merugikan organisasi itu sendiri. Oleh karena itu, koordinasi dengan kinerja produksi suatu perusahaan haruslah seiring, karena dengan koordinasi, efektivitas dalam hal output dan efisiensi dalam hal input pada suatu proses produksi dapat mencapai tujuan produksi yang maksimal sesuai target.

\subsection{Perencanaan Terhadap Kinerja Produksi}

Perencanaan

produksi, implementasi, proses dan inventory control adalah pusat dari supply chain diberbagai jenis perusahaan tranding dan manufacturing. Mengelola proses produksi secara secara bukan hanya memastikan operasional yang mulus dan efisien tetapi juga akan menentukan dan menbedakan perusahaan, sebagai komponen yang besar dalam keunggulan kompetitif. Tanggung jawab perencanaan meliputi pengelolaan produksi termasuk memastikan tingkat proses produksi yang efisien dan efektif dengan daya sumber kekuatan yang siap untuk beradaptasi dengan peralatan baru dan jadwal, menelusuri materi dasar, komponenkomponennya, work in progress, finished goods, dan routing termasuk definable information, paperwork, dan dokumentasi. Financial dan inventory control tergabung dalam monitoring opertions adalah hal yang penting untuk memastikan output levels dan cost levels tercapai. Suatu perencanaan merupakan pokok penting suatu kinerja produksi perusahaan, khususnya dalam hal guna mencapai hasil produksi sesuai target yang ditetntukan oleh perusahaan.

\section{Kerangka Pikir/ Kerangka Konsep}

Kerangka pemikiran adalah seluruh kegiatan penelitian sejak dari penelitian, pelaksanaan sampai dengan penyelesaiannya dalam satu kesatuan yang utuh. Guna memudahkan dan memahami inti pemikiran penulis, maka perlu kiranya dibuat kerangka pemikiran dari masalah yang diangkat, yang akan di gambarkan sebagai berikut.

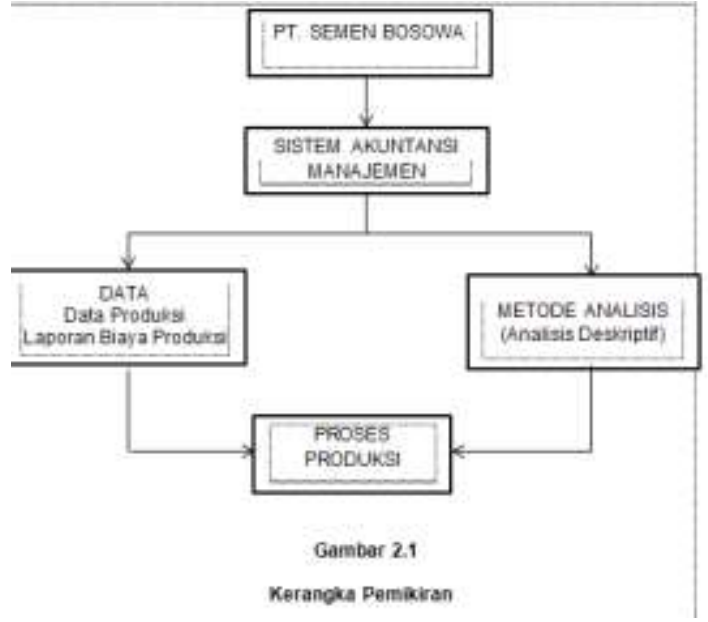

\section{METODE PENELITIAN}

\subsection{Tekhnik Pengumpulan Data}

Tekhnik pengumpulan data merupakan langkah yang paling strategis dalam penelitian, karena tujuan utama dari peneltian adalah mendapatkan data. Tanpa mengetahui tekhnik pengumpulan data, maka peneliti tidak akan mendapatkan data yang memenuhi standar yang ditetapkan. (Sugiyono, 2017:224). Adapun tekhink pengumpulan data dalam penelitian ini yaitu: 


\section{Observasi}

Observasi adalah dasar semua ilmu pengetahuan. Para ilmuan hanya dapat bekerja berdasrkan data, yaitu fakta mengenai dunia kenyataan yang diperoleh melalui observasi. Data itu dikumpulkan dan seiring dengan bantuan berbagai alat yang sangat canggih sehingga benda-benda yang sangat kecil (proton dan electron) maupun yang sangat jauh dapat di observasi dengan jelas.

Berdasarkan penjelasan tersebut dalam penelitian ini, peneliti melakukan observasi atau pengamatan secara langsung untuk menyelidiki masalahmasalah yang terjadi guna memperoleh data yang sekiranya mendukung penelitian ini.

\section{Wawancara.}

Wawancara merupakan pertemuan dua orang untuk bertukar informasi dan ide melalui tanya jawab, sehingga dapat dikonstruksikan makan dalam suatu topic tertentu. Untuk memperoleh data dalam mendukung penelitian ini, peneliti melakukan wawancara langsung dengan Manajer/kepala bagian produksi serta karyawan atau tenaga kerja produksi PT. Semen Bosowa Maros.

\section{Dokumentasi}

Dokumen merupakan catatan peristiwa yang sudah berlalu. Dokumen bisa berupa tulisan, gambar atau karya monumental dari seseorang. Dokumen berupa tulisan misalnya catatan harian, sejarah kehidupan, biografi, peraturan, kebijakan. Dokumen yang berbentuk gambar misalnya foto, gambar hidup sketsa dan lain lain. Dokumen yang berbentuk karya berupa karya seni, yang dapat berupa gambar, film, patung dan lain lain. Studi dokumentasi merupakan pelengkap dari penggunaan metode observasi dan wawancara dalam penelitian kualitatif. Untuk pengumpulan data melalui dokumentasi dalam penelitian ini, peneliti menggunakan dokumentasi berupa gambar (media fotografi

\subsection{Instrumen Penelitian}

Dalam penelitian kualitatif instrument utamanya adalah peneliti itu sendiri, namun selanjutnya setelah fokus penelitian menjadi jelas, maka kemungkinan akan dikembangkan instrument penelitian sederhana, yang diharapkan dapat melengkapi data dan membandingkan dengan data yang telah ditemukan melalui observasi dan wawancara. Peneliti akan terjun ke lapangan sendiri, baik pada grand tour question, tahap focused and selection, melakukan pengumpulan data, analisis dan membuat kesimpulan. (Sugiyono, 2017:223-224).

Berdasarkan penjelasan diatas, adapun alat yang digunakan penulis dalam menggali data pada penelitian ini yakni metode observasi dan wawancara. Penulis memilih instrumen tersebut dikarenakan metode ini dinilai sebagai alat yang langsung menyelidiki bermacam-macam gejala terjadi yang berkaitan dengan hal yang akan diteliti, serta nantinya setiap pertanyaan yang disediakan dapat dijawab oleh narasumber dengan penjelasan penjelasan tambahan.

\subsection{Tekhnik Analisis Data}

Adapun teknik analisis data yang digunakan dalam penelitian ini adalah analisis data model Miles dan Huberman. Aktivitas dalam analisis data ini yaitu:

1. Reduksi data (data reduction)

Mereduksi data berarti merangkum, memilih hal-hal yang pokok, memfokuskan pada hal-hal penting, dicari tema dan polanya. Dalam penelitian ini, penulis merangkum hal-hal penting atau 
tema utama yang akan dikaji sebagai pemfokusan yaitu tentang bagaimana perencanaan terhadap operasi produksi, pengendalian terhadap operasi produksi, serta koordinasi kinerja produksi.

\section{Penyajian Data (data display)}

Setelah data direduksi maka langkah selanjutnya adalah mendisplaykan data. Dalam penelitian kualitatif penyajian data bisa dilakukan bentuk uraian singkat, bagan, hubungan antar kategori, flowchart, dan sejenisnya. Untuk langkah ini penulis menyajikan suatu hasil wawancara serta flowchart alur kebijakan yang diterapkan oleh pihak manajemen PT. Semen Bosowa kemudian diuraikan secara bertahap sesuai temuan yang ada dilapangan.

\section{Verifikasi (conclusion drawing)}

Langkah ketiga dalam analisis data menurut Miles dan Huberman adalah penarikan kesimpulan dan verifikasi. Kesimpulan awal yang dikemukakan masih bersifat sementara, dan akan berubah bila tidak ditemukan bukti-bukti yang kuat yang kuat yang mendukung pada tahap pengumpulan data berikutnya. Tetapi apabila kesimpulan yang dikemukakan pada tahap awal, didukung oleh bukti-bukti yang valid dan konsisten saat peneliti kembali ke lapangan mengumpulkan data, maka kesimpulan yang dikemukakan merupakan kesimpulan yang kredibel. Kesimpulan dalam penelitian kualitatif adalah merupakan temuan baru yang sebelumnya belum pernah ada. Temuan dapat berupa deskripsi atau gambaran suatu obyek yang sebelumnya masih remang-remang atau gelap sehingga setelah diteliti menjadi jelas, dapat berupa kausal atau interaktif, hipotesis atau teori.

\section{HASIL DAN PEMBAHASAN}

\subsection{Kebijakan Akuntansi Manajemen PT Semen Bosowa Maros}

Berdasarkan hasil penelitian yang dilakukan oleh peneliti, maka ditemukan beberapa dokumen yang menunjukkan adanya upaya dalam mewujudkan visi dan misi perusahaan dengan menerapkan sistem manajemen perusahaan yang terintegrasi dan terpadu. Dokumendokumen tersebut menunjukkan bahwa PT Semen Bosowa Maros telah menerapkan kebijakan Sistem Manajemen Mutu ISO 9001, Sistem Manajemen Lingkungan ISO 14001 dan Sistem Manajemen Keselamatan dan Kesehatan Kerja (SMK3), yang secara rinci akan dijelaskan sebagai berikut:

a. Sistem Manajemen Mutu

Sebagai upaya untuk berkomitmen dalam peningkatan mutu, PT Semen Bosowa Maros telah menerapkan Sistem Manajemen Mutu. Jaminan mutu dan kepuasan konsumen merupakan komitmen manajemen dalam menghadapi persaingan yang ketat dengan produsen semen lainnya. Pemenuhan komitmen tersebut terwujud dalam upaya pemenuhan kualitas produk sesuai permintaan konsumen dan penyerahan produk yang tepat waktu dengan harga yang bersaing.

b. Sistem Manajemen Lingkungan

Manajemen perseroan mempunyai komitmen untuk "menjadi produsen semen yang ramah lingkungan". Komitmen tersebut diwujudkan dengan penerapan Sistem Manajemen Lingkungan sesuai pemenuhan persyaratan yang berlaku; meminimasi dampak negatif dari operasi dan produk; pelaksanaan program efisiensi pemakaian sumber daya alam dan energi; melaksanakan kegiatan konservasi lahan bekas tambang; serta membina hubungan 
harmonis dengan masyarakat sekitar. Selain itu, PT Semen Bosowa Maros juga menerapkan kebijakan lingkungan bertujuan meningkatkan keramahan lingkungannya dengan memperhatikan, menetapkan, menerapkan, memelihara dan meningkatkan sistem manajemen lingkungan.

c. Manajemen Kesehatan dan Keselamatan Kerja

Perseroan menyadari bahwa tenaga kerja merupakan asset perseroan yang sangat penting keberadaannya dalam mendukung kelangsungan operasional perusahaan, maka kondisi keselamatan dan kesehatan karyawan harus dijamin. Untuk itu, manajemen perseroan berkomitmen mempertahankan kondisi lingkungan kerja yang aman, sehat dan sejahtera, bebas dari kecelakaan dan pencemaran lingkungan serta penyakit kerja yang diwujudkan lewat penerapan Sistem Manajemen Keselamatan Kerja (SMK3) yang terkandung dalam Kebijakan Sistem Keselamatan dan Kesehatan Kerja PT Semen Bosowa Maros.

\subsection{Sistem Akuntansi Manajemen PT Semen Bosowa Maros}

Berdasarkan hasil penelitian yang dilakukan oleh peneliti , Sistem Akuntansi Manajemen PT Semen Bosowa diterapkan secara sistematis dan tersturuktur. Hal ini dikarenakan Sistem Akuntansi Manajemen merupakan langkah dalam menentukan tahapan-tahapan yang akan dilakukan dalam pelaksanaan operasi produksi sehingga mampu mencapai hasil yang optimal dalam aktivitas produksi tersebut

\subsection{Proses Produksi PT Semen Bosowa Maros}

Semen yang diproduksi PT. Semen Bosowa Maros adalah jenis OPC (Ordinary
Portland Cement) yang biasanya digunakan untuk membuat beton dan bangunan bertingkat dan jenis PCC (Portland Composite Cemen) yang digunakan untuk pemakaian umum. Bahan baku yang digunakan untuk menghasilkan semen jenis jenis OPC dan PCC sama yaitu terdiri dari klinker, limestone, silica sand, coal, sludge, clay, gypsum dan trass, yang membedakan terletak pada komposisi bahan baku yang digunakan. Untuk OPC menggunakan klinker dan gypsum lebih besar dari OPC.

Lokasi peledakan ditentukan secara terukur untuk mencegah terjadinya hal yang berbahaya, misalnya longsor. Batu kapur yang diledakkan dengan menggunakan mobil tirex dan hasilnya sudah terukur. Begitu pula dengan tanah liat yang digunakan, diangkut dengan menggunakan mobil tirex ke tempat penampungan yang disebut crasher. Batu kapur yang diangkut langsung dimasukkan ke dalam crasher untuk dipecah menjadi batu dengan ukuran tertentu.

Proses pembuatan semen PT Semen Bosowa Maros menggunakan proses kering yakni umpan raw mill hanya mengandung kadar air sebesar 1\%.

\subsection{Evaluasi Sistem Akuntansi Manajemen Pada PT Bosowa Maros}

Berdasarkan hasil dibagian 2 tentang sistem akuntansi manajemen PT Semen Bosowa Maros, bahwa dengan adanya evaluasi sistem akuntansi manajemen yang dilaksanakan dapat menjaga kelancaran proses produksi pada PT Semen Bosowa Maros. Evaluasi sistem akuntansi manajemen yang dilakukan manajemen produksi sangat berperan penting terhadap kelancaran proses produksi PT Semen Bosowa Maros yang 
dilihat dari fungsi evaluasi sistem akuntansi manajemen dalam perencanaan, pengendalian serta koodirnasi kinerja produksi. Sistem akuntansi manajemen tidak terikat oleh suatu kriteria formal yang menjelaskan sifat input atau proses dan output. Kriteria tersebut fleksibel dan berdasarkan tujuan yang ingin dicapai atau telah ditetapkan.

1. Perhitungan harga pokok dan biaya periode

Perhitungan harga pokok dan biaya periode yaitu mengukur biaya sumber daya yang dipakai untuk memproduksi produk dan memasarkan konsumen

2. Pengendalian manajemen dan operasional

Pengendalian operasional yaitu menyediakan informasi tentang prestasi manajer dan unit-unit pelaksanaan dalam organisasi. Budget merupakan unsur penting dalam pengendalian

3. Pengendalian strategis

Pengendalian strategis yaitu menyediakan informasi tentang prestasi jangka panjang dan keuangan perusahaan, kondisi pasar dan inovasi tekhnologi untuk mengantisipasi perubahaan dimasa mendatang. Berdasarkan adanya evaluasi sistem akuntasi manajemen yang dilakukan PT Semen Bosowa Maros maka tingkat biaya yang mengalami kenaikan selama 5 tahun terakhir mempengaruhi total jumlah produksi yang menurun seperti pada tabel berikut:
Tabel 4.1

Data Produssi dan Biaja Produksi PT Semen Bcsowa

\begin{tabular}{|c|c|c|c|}
\hline $\mathbb{N o}$ & $\begin{array}{l}\text { Tahun } \\
\text { Anggasan }\end{array}$ & $\begin{array}{c}\text { Jungh Prodiks } \\
\text { (ton) }\end{array}$ & $\begin{array}{c}\text { Totel Biygs Produks } \\
\text { (Rp) }\end{array}$ \\
\hline 1 & 2014 & 1.702401 & 6145653.375625 \\
\hline 2 & 2015 & 1604562 & 719242620627 \\
\hline 3 & 2016 & 1622575 & 1.048 .103 .45 .812 \\
\hline 4 & 2017 & 1587.834 & 1.117016 .703 .618 \\
\hline 5 & 2018 & 1.531 .217 & 1218863.351 .52 \\
\hline
\end{tabular}

Tabel 4.1 menunjukkan bahwa jumlah produksi PT Semen Bosowa terus mengalami penurunan. Tingkat penurunan jumlah produksi terjadi sejak tahun 2014 sampai pada tahun 2018. Tingkat penurunan terjadi dikarenakan permintaan jumlah semen dikawasan Indonesia timur juga mengalami penurunan, hal ini juga dilakukan guna untuk mengantisipasi agar perusahaan tidak mengalami kerugian akibat over produksi.

\subsection{Pembahasan Penelitian}

Evaluasi Sistem Akuntansi Manajemen Terhadap Kelancaran Proses Produksi PT Semen Bosowa Maros dilakukan oleh manajemen produksi PT Semen Bosowa Maros. Manajemen produksi melakukan evaluasi terhadap serangkaian proses yang berkaitan langsung dengan jalannya proses produksi semen pada PT Semen Bosowa Maros.

Berdasarkan hasil penelitian yang dilakukan oleh peneliti, evaluasi sistem akuntansi manajemen terhadap kelancaran proses produksi pada PT Semen Bosowa Maros dapat dilihat dari beberapa unsur sebagai berikut: 


\section{Perencanaan terhadap proses produksi.}

Perencanaan produksi merupakan salah satu hal penting dalam untuk menunjang kelancaran proses produksi perusahaan. Berdasarkan hasil penelitian yang peneliti lakukan evaluasi sistem akuntansi manajemen yang diterapkan oleh manajemen produksi PT Semen Bosowa Maros dalam tahap perencanaan telah dilakukan dengan baik. hal ini dikarenakan pihak manajemen produksi melakukan analisa sebaik mungkin dengan cara berkomunikasi pada bagian departemen lainnya yang terdapat pada perusahaan untuk memastikan adanya perencanaan yang tepat guna mendukung kelancaran proses produksi.

Evaluasi Sistem Akuntansi Manajemen dilakukan untuk menghindari kesenjangan antar produk yang diminta dengan produk yang dihasilkan perusahaan, sebagaimana langkah pertama siklus perencanaan produksi yaitu production proposal. Langkah ini dilakukan untuk membantu perusahaan untuk menyusun suatu cara pemanfaatan sumber daya perusahaan secara optimal, sehingga dapat mencapai kapasitas produksi yang efektif dan efisien. Fungsi perencanaan diterapkan untuk menilai tingkat permintaan pasar yang diharapkan dapat disediakan perusahaan dimasa produksi yang akan datang. Hasil dari perencanaan produksi adalah sebuah rencana produksi yang merupakan faktor penting untuk keberlangsungan proses produksi PT Semen Bosowa Maros sehingga faktor penghambat kelancaran proses produksi dapat diminimalisir sehingga proses produksi yang efektif dan efisien dapat tercapai.

Kegiatan perencanaan produksi sebagai salah satu bagian dari manajemen produksi sangat menentukan bagaimana produksi semen berjalan. Proses perencanaan yang ada pada PT Semen Bosowa Maros bersifat luwes dan terbuka sehingga apabila suatu perubahan diperlukan maka hal tersebut dapat dilakukan untuk memaksimalkan proses produksi. Sifat terbuka ini ditunjang dengan monitor yang terus menerus dilakukan agar perencanaan tetap pada tujuan yang telah ditetapkan.

\section{Pengendalian Terhadap Operasi Produksi}

a. Pengendalian terhadap bahan baku

Berdasarkan penelitian yang dilakukan oleh peneliti, pengendalian bahan baku merupakan hal penting yang senantiasa diperhatikan manajemen PT Semen Bosowa Maros. Manajemen produksi menyadari benar bahwa bahan baku merupakan unsur penting demi kelancaran proses produksi maka pengedelian terhadap kebenaran bahan baku harus diperhatikan. Pengendalian bahan baku produksi semen bosowa dilaksanakan sebaik-baiknya, sehingga persediaan bahan baku yang ada dapat menunjang pelaksanaan operasi produksi perusahaan.

Untuk mengetahui besarnya kebutuhan bahan baku yang diperlukan perusahaan pada suatu periode tertentu maka manajemen produksi PT Semen Bosowa Maros menggunakan data yang cukup relevan untuk mengadakan peramalan kebutuhan bahan baku. Beberapa data yang digunakan dalam penyusunan peramalan persediaan bahan baku ini antara lain adalah data dari perencanaan produksi yang akan dilaksanakan PT Semen Bosowa pada periode yang telah ditentukan. Disamping data tersebut, manajemen produksi menggunakan data penggunaan bahan baku dari periode yang telah lalu. Kebutuhan bahan baku untuk suatu 
produksi pada umumnya relative sama dari waktu ke waktu, sehingga perubahan dari jumlah semen yang diproduksi akan berakibat terjadinya perubahan jumlah kebutuhan bahan baku yang diperlukan untuk melaksanakan proses produksi tersebut.

Hasil penelitian juga didapatkan bahwa masalah persediaan, terutama persediaan bahan baku merupakan suatu hal penting. Untuk mengantisipasi kekurangan bahan baku yang tersedia pada saat musim hujan yang dapat berakibat terhentinya proses produksi karena habisnya bahan untuk diproses. Hal ini membuat pihak manajemen produksi PT Semen Bosowa Maros khususnya saat musim kemarau manajemen menambah stock bahan baku secara terencana guna untuk mengatasi kurangnya bahan baku sehingga proses produksi tetap dapat berjalan.

Pelaksanaan pengendalian terhadap kelancaran produksi PT Semen Bosowa Maros dilakukan oleh manajemen produksi perusahaan sebagai evaluasi untuk meminimalisir hambatanhambatan yang mungkin terjadi terutama supply bahan baku berupa clay dan silica dapat terjaga sehingga proses produksi semen dapat berjalan sesuai tahap perencaan awal yang telah ditentukan sebelumnya.

b. Pengendalian terhadap biaya produksi Berdasarkan hasil penelitian yang peneliti lakukan, dalam mengendalikan biaya produksi, PT Semen Bosowa Maros menggunakan anggaran sebagai alat pengendalian biaya. Dengan adanya anggaran, biaya dapat direncanakan jumlahnya sebelum melakukan aktivitas produksi. Dalam penyusunan anggaran biaya PT Semen Bosowa Maros menggunakan data dan informasi biaya dari pengalaman tahun sebelumnya. Penggunaan anggaran diperhitungkan secara cermat, sehingga biaya dapat terkontrol atau disesuaikan dengan jumlah semen yang akan diproduksi pada periode tertentu.

Hasil penelitian menunjukka adanya kenaikan biaya produksi PT Semen Bosowa pada tahun 2014 - 2018 dikarenakan biaya bahan baku yang setiap tahunnya juga mengalami kenaikan, hal ini juga sejalan dengan biaya tenaga kerja langsung serta biaya overhead pabrik yang harus dikeluarkan oleh perusahaan sehingga produksi tahunan mendapat penyesuaian pula setiap tahunnya yakni pada tahun 20142018 terus mengalami penurunan, kenaikan biaya produksi dan penurunan produksi membuat pihak manajemen perusahaan terus mengadakan evaluasi untuk memperhatikan kondisi pasar serta memastikan realisasi biaya berjalan efisien dan efektif agar dapat tercapai laba yang optimal.

c. Pengendalian Terhadap Karyawan/Tenaga Kerja Produksi Berdasarkan hasil penelitian yang peneliti lakukan, pengendalian terhadap karyawan/tenaga kerja produksi yang dilakukan manajemen PT Semen Bosowa Maros telah dilakukan dengan baik. dimana untuk memaksimalkan tugas dan tanggungjawab pekerja, manajemen menerapkan pembagian kerja berdasarkan kemampuan dan keterampilan para pekerja produksi yang terlibat langsung saat proses produksi. Pembagian kerja dilakukan dengan menempatkan pekerja dalam 1 (satu) shift yang mana setiap shift bekerja selama 8 (delapan) jam kerja.

Pekerja ditempatkan diarea sesuai kemampuan serta keterampilan yang dimiliki, kualitas dan kuantitas tenaga kerja merupakan hal yang mendapat perhatian serius oleh pihak manajemen PT Semen Bosowa Maros. Batasan akan 
jumlah pekerja yang bisa berada dalam lingkup produksi/pabrik membuat manajemen melakukan pemberdayaan terhadap pekerja agar nantinya pekerja yang ada bisa atau dapat mencover beberapa area tertentu, selain itu pekerja juga diberdayakan dengan tujuan untuk mengontrol peralatan-peralatan yang akan digunakan pada saat proses produksi untuk mencegah hasil produk/semen dari proses produksi yang cacat atau tidak sesuai standar mutu yang ditetapkan akibat alat produksi yang rusak.

Pengendalian karyawan/tenaga kerja produksi adalah serangkaian pengawasan yang dilakukan manajemen PT Semen Bosowa untuk meminimalisir adanya penyimpangan yang dapat berpengaruh pada saat proses produksi sehingga seluruh rangkaian yang telah direncanakan, diorganisasikan dan diimplementasikan dapat berjalan sesuai dengan yang diharapkan.

3. Perencanaan terhadap koordinasi kinerja produksi

Koordinasi kinerja produksi PT Semen Bosowa menjadi pedoman terhadap lingkungan yang dinamis dan sulit diramal. Berdasarkan penelitian yang dilakukan peneliti PT Semen Bosowa dalam menunjang kelancaran proses produksinya senantiasa melakukan rapat kordinasi yang membahas kondisi internal ataupun kondisi eksternal yang dapat berpengaruh pada proses produksi.

Rapat koordinasi yang dilakukan setiap bulan September dengan departemen lain menghasilkan evaluasi untuk menyusun program-program perbaikan akan kelancaran operasioanal produksi dan inovasi-inovasi peningkatan kinerja. Evaluasi peningkatan kinerja juga digunakan manajemen produksi PT Semen Bosowa Untuk merumuskan kembali prioritas selama kegiatan proses produksi berjalan. Koordinasi pada setiap unit yang berkaitan pada pelaksanaan produksi dilakukan secara terorganisir dengan cara komunikasi yang berkelanjutan antara karyawan/tenaga kerja dengan pihak manajemen perusahaan. Hal ini dilakukan agar terdapat sinergi yang baik sehingga pelaksanaan proses produksi mulai dari tahap perencanaan sampai dengan produksi semen dilakukan semua proses tersebut dikerjakan secara optimal sehingga tujuan perusahaan yang telah ditentukan dapat dicapai. produksi tahunan mendapat penyesuaian pula setiap tahunnya yakni pada tahun 20142018 terus mengalami penurunan, kenaikan biaya produksi dan penurunan produksi membuat pihak manajemen perusahaan terus mengadakan evaluasi untuk memperhatikan kondisi pasar serta memastikan realisasi biaya berjalan efisien dan efektif agar dapat tercapai laba yang optimal.

4. Pengendalian Terhadap Karyawan/Tenaga Kerja Produksi

Berdasarkan hasil penelitian yang peneliti lakukan, pengendalian terhadap karyawan/tenaga kerja produksi yang dilakukan manajemen PT Semen Bosowa Maros telah dilakukan dengan baik. dimana untuk memaksimalkan tugas dan tanggungjawab pekerja, manajemen menerapkan pembagian kerja berdasarkan kemampuan dan keterampilan para pekerja produksi yang terlibat langsung saat proses produksi. Pembagian kerja dilakukan dengan menempatkan pekerja dalam 1 (satu) shift yang mana setiap shift bekerja selama 8 (delapan) jam kerja.

Pekerja ditempatkan diarea sesuai kemampuan serta keterampilan yang dimiliki, kualitas dan kuantitas tenaga 
kerja merupakan hal yang mendapat perhatian serius oleh pihak manajemen PT Semen Bosowa Maros. Batasan akan jumlah pekerja yang bisa berada dalam lingkup produksi/pabrik membuat manajemen melakukan pemberdayaan terhadap pekerja agar nantinya pekerja yang ada bisa atau dapat mencover beberapa area tertentu, selain itu pekerja juga diberdayakan dengan tujuan untuk mengontrol peralatan-peralatan yang akan digunakan pada

\section{PENUTUP}

\subsection{Kesimpulan}

Adapun kesimpulan yang dapat diambil dari hasil penelitian ini adalah sebagai berikut:

1. Evaluasi sistem akuntansi manajemen yang dilakukan pada PT Semen Bosowa Maros telah dilakukan dengan baik hal ini karena Evaluasi Sistem Akuntansi manajemen dilakukan secara sistematis dan terstruktur mulai saat perencanaan produksi, pengendalian proses produksi serta koordinasi kinerja untuk memastikan kelancaran proses produksi.

2. Produksi tahunan PT Semen Bosowa mulai tahun 2014 sampai tahun 2018 mengalami penurunan sebagai penyesuaian tingkat realisasi biaya yang meningkat pula pada tahun tersebut, serta jumlah permintaan pasar juga mengalami penurunan.

3. Peranan evaluasi sistem akuntansi manajemen terhadap kelancaran proses produksi PT Semen Bosowa Maros sangat berperan penting untuk mengoptimalkan sumber daya yang terdapat pada perusahaan. Dengan adanya evaluasi yang dilakukan PT Semen Bosowa Maros pihak manajemen dapat mengumpulkan segala informasi dan data-data untuk menjamin kelancaran dan mengatasi hambatan-hambatan yang dapat terjadi pada saat produksi

\subsection{Saran}

Berdasarkan hasil pengamatan dan kesimpulan yang telah dikemukan, penulis dapat memberikan saran kepada pihak manajemen PT Semen Bosowa Maros dan peneliti selanjutnya, sebagai berikut

1. PT Semen Bosowa Maros

Perlunya tindakan lanjutan atas evaluasi sistem akuntansi manajemen terutama untuk memastikan jumlah produksi tetap signifikan atau rata-rata jumlah produksi tidak jauh berbeda ditahun produksi yang sebelumnya.

2. Manajemen Produksi

Manajemen Produksi diharapkan dapat terus menjamin produksi tahunan tetap berjalan sesuai program-program perencanaan produksi, selain tetap memperhatikan permintaan juga untuk memastikan produksi tahunan tetap relevan dengan adanya kenaikan biaya produksi setiap masa produksi selanjutnya.sehingga kerugian perusahaan dapat diatasi dan menghasilkan laba sesuai target yang telah ditentukan.

\section{Bagi peneliti selanjutnya}

Peneliti selanjutnya diharapkan untuk mengkaji lebih banyak sumber atau refrensi yang terkait dan dalam proses pengambilan dan pengumpulan data harus mempersiapka diri terhadap kendala-kendala yang akan didapat pada saat melakukan penelitian . Peneliti selanjutnya diharapkan ditunjang pula dengan instrument wawancara menggunakan internal control kuesioner agar penelitian yang dilakukan lebih lengkap dan lebih baik lagi. 


\section{DAFTAR PUSTAKA}

Ahmad, K. (2014). In D.-d. K. Keputusan, Akuntansi Manajemen (Edisi 3 ed., p. 3). Jakarta: Rajawali Pers.

Harti Budiyanti, d. (2013). In M. P. Manajemen, \& R. Brontolaras (Ed.), Akuntansi Manajemen (Edisi 2 ed., p. 1.9). Tanggerang Selatan: Universitas Terbuka.

Ira Rahmawati, Y. R., \& Nurleli. (2017). Pengaruh Karakteristik Sistem Akuntansi Manajemen Terhadap Kinerja Manajerial Dengan Ketidakpastian Lingkungan Sebagai Variabel Moderating. Prosiding Akuntansi, 3(2), 93-100.

Janrilius Doli Butarbutar, H. K. (2017). Analisis Penerapan Sistem Akuntansi Manajemen Terhadap Kualitas Produk Di PT. Empat Saudara Manado. Jurnal Riset Akuntansi Going Concern, 12(1), 187-193.

Kurnia, D. (2015). Analisis Sistem Akuntansi Manajemen Pada Perusahaan Manufaktur Di Kabupaten Serang Implikasinya Pada Kelangsungan Hidup Perusahaan. Jurnal Akuntansi, 2(1), 86-102.

Majid, J. (2013). Akuntansi Manajemen. In R. D. Ayu (Ed.), Memahami Akuntansi Manajemen (p. 2). Makassar: Alauddin University Press.

Nadia Lanny Tengor, V. I., \& Tirayoh, V. Z. (2016). Pengaruh Sistem Akuntansi Manajemen Terhadap Pengendalian Biaya Kualitas Produk Pada CV. Sarana Marine Fiberglass Manado. Jurnal Emba, 4(1), 272-282.
Puspitawati, L., \& Anggadani, S. D. (2011). Sistem Informasi Akuntansi. In Sistem Informasi Akuntansi (p. 57). Yogyakarta: Graha Ilmu.

Sugiyono. (2017). Metode Penelitian. In Kuantitatif, Kualitatif, $R \& D$ ( $p$. 224). Bandung: ALFABETA.

Sujarweni, V. W. (2015). Akuntansi Manajemen. In A. Manajemen, Teori \& Aplikasi (p. 5). Yogyakarta: Pustaka Baru Press Yogyakarta.

Sunyoto, D. (2016). Metodologi Penelitian Akuntansi. Bandung: PT Refika Aditama.

Sutisman, E., \& Putra, G. H. (2017). Pengaruh Sistem Akuntansi Manajemen Terhadap Kinerja Produksi Pada PT. X. Jurnal Future, 4(2), 198-214.

Yuliana, \& Friyani, R. (2017). Pengaruh Karakteristik Sistem Akuntansi Manajemen Terhadap Kinerja Manajerial Dengan Desentralisasi Dan Locus of Control Sebagai Variabel Moderasi Pada Perusahaan Manufaktur Di kota Jambi. Jurnal Sains Sosio Humaniora, 1(2), 149-155. 